\title{
"Are problems during pregnancy a predictor of childbirth in the hospital?" Determinants Analysis of Hospital Childbirth in Urban Poor Communities in Indonesia
}

\author{
Ratna Dwi Wulandari ${ }^{1}$, Agung Dwi Laksono ${ }^{2}$ \\ ${ }^{1}$ Faculty of Public Health, Universitas Airlangga, Surabaya, Indonesia. Campus C Mulyorejo, \\ Surabaya, Indonesia \\ ${ }^{2}$ National Institute of Health Research and Development, the Ministry of Health of the Republic \\ of Indonesia. J1. Percetakan Negara 29, Jakarta, Indonesia \\ *Corresponding Author: \\ Ratna Dwi Wulandari. Email: ratna-d-w@fkm.unair.ac.id
}

\begin{abstract}
Background: Although hospital services were available, urban poor people often have limited access to hospitals when needed. This study was conducted to analyze the determinants of childbirth in a hospital in urban poor women in Indonesia.

Methods: The analysis in this study uses raw data from the 2017 IDHS. With stratification and multistage random sampling, 7891 women aged 15-49 years in urban poor communities with live births in the last 5 years were sampled. Data were analyzed using a Binary Logistic Regression test.

Results: The results of the study found that "problems during pregnancy" was not proven as a determinant of the hospital use for delivery in urban poor women in Indonesia. Age was proven to be one of the determinants, while in the education level category, urban poor women with tertiary education were 2.506 times more likely to use hospitals for delivery than urban poor women who were not in school. Parity was significantly proven as one of the determinants that influence the use of hospital for delivery in urban poor women in Indonesia. Urban poor women who were covered by health insurance have 1.933 times more possibility of utilizing hospital for delivery than those who do not have health insurance. It could be concluded that "problem during pregnancy" variable was not a predictor of the hospital use for childbirth in the urban poor community in Indonesia.

Conslusions. The determinants or variables that influence, on the hospital use for childbirth were age, education level, parity, and ownership of health insurance.
\end{abstract}

Keywords: urban poor community, pregnancy problems, wealth status, childbirth, facility-based childbirth 


\section{BACKGROUND}

Maternal Mortality Rate (MMR) in Indonesia is still quite high, even when compared to countries in the Southeast Asia region. In 2015 MMR was recorded at 305 per 100,000 live births. This achievement has decreased compared to MMR in 2012 which was in the range of 359 per 100,000 live births. This milestone is documented in the 2016 Annual Report of Directorate of Family Health ${ }^{1}$.

The 2017 Indonesian Demographic Data Survey (IDHS) results found that 74\% of women in Indonesia gave birth in health care facilities. As many as $42 \%$ deliver at first-level health service facilities, which include the Health Center (Puskesmas) and its network, clinics, and practices of health workers. While there are $32 \%$ who deliver at the advanced level of referral service facilities, namely hospitals ${ }^{2}$.

Urban poor people like living in a vicious circle. Between poor, uneducated, and sick, like a chain that is difficult to break ${ }^{3,4}$. Urban poor people tend to form their own colonies in urban slums. This condition is often due to high housing and land prices in urban areas ${ }^{5,6}$. Slum housing conditions actually increase the risk of the urban poor to fall ill ${ }^{7,8}$. The government must pay serious attention to the urban poor. This group of people tends to neglect health issues because they have little education. The urban poor tend to prioritize work matters rather than school and health matters ${ }^{9}$.

Although hospital services were available, urban poor people often have limited access to hospitals when needed. This situation could occur because of their ignorance, or because they did not have health insurance ${ }^{10,11,12}$.

Based on the background, this article was prepared to analyze the determinants of childbirth hospitals in urban poor communities in Indonesia. The analysis in this study is useful for policymakers in the field of maternal health to formulate more detailed policies according to the targets identified in the study results. This step is necessary to ensure the reduction of obstacles for urban poor women to access maternity services in hospitals.

\section{METHODS}

\section{Data Source}

Secondary data from the 2017 Indonesian Demographic Data Survey (IDHS) was used as analysis material in this study. The IDHS was part of the international Demographic and Health Survey (DHS) program conducted by the Inner City Fund (ICF). In Indonesia context, the 2017 IDHS was carried out by the Central Statistics Agency (BPS), in collaboration with the National Population and Family Planning Board (BKKBN) and the Ministry of Health.

The 2017 IDHS sample was determined through stratification and multistage random sampling. The unit of analysis in this study was women aged 15-49 years old who had given birth in the last 5 years. The sample size of the 2017 IDHS used in this analysis was 7,891 women.

\section{Procedure}

The 2017 IDHS has passed ethical tests from the National Institute for Health Research and Development of the Indonesian Ministry of Health. The respondents' identities have all been deleted from the dataset. Respondents have provided written approval for their involvement in the study. The use of the 2017 IDHS data for this study has received permission from ICF International through its website: https://dhsprogram.com/data/new-user-registration.cfm. 


\section{Data Analysis}

Problems during pregnancy were the respondent's acknowledgment of problems experienced during pregnancy until delivery. These problems consist of: prolonged labor, vaginal bleeding, fever, convulsions, baby in the wrong position, swollen limbs, faint, breathlessness, tiredness, and others ${ }^{2}$.

Socioeconomic was wealth status of respondent compiled based on index of goods ownership quintile stated by the respondent. The five categories were poorest (quintile 1), poorer (quintile 2), middle (quintile 3), richer (quintile 4), and richest (quintile 5). The urban poor category used in this study was people who live in urban areas and with wealth status in quintiles 1 and 2.

The 2017 IDHS data was obtained through a structured questionnaire. Variables analyzed included, age, education level, work status, marital status, parity, health insurance, and antenatal care. Statistical analysis using chi-square was carried out for dichotomous variables and t-test for continuous variables. This statistical analysis was conducted to assess whether there were differences in childbirth facility that were statistically significant between the category of wealth status. Estimates were performed using Binary Logistic Regression because of the nature of the dependent variable. All statistical analyses were carried out using SPSS 19 software.

\section{RESULTS}

Table 1 informs descriptive statistics on the category of "problems during pregnancy" in urban poor women who have given birth in the last five years in Indonesia. Table 1 shows that there are significant differences in urban poor women who have given birth in the last five years in the use of hospitals for delivery in Indonesia. This difference is statistically significant for all observed characteristics. Table 1 informs that urban poor women who have delivered in the last five years have more dominant non-hospital deliveries.

Table 1 shows that urban poor women who gave birth in the last five years had a slightly older average age for those who did not have problems during pregnancy. Urban poor women who have given birth in the last five years predominantly have secondary education and are unemployed.

Table 1 informs that urban poor women who gave birth in the last five years were dominated by women with marital status married/living with partners. Urban poor women who have given birth in the last five years have a slightly higher average parity in those who have no problems during pregnancy.

Table 1 shows that urban poor women who gave birth in the last five years were dominated by women covered by health insurance. Urban poor women who have given birth in the past five years have been dominant for antenatal care more than 4 times before giving birth.

Table 2 presents the results of the binary logistic regression test to illustrate the results of the analysis of determinants of the use of hospitals for delivery in urban poor women in Indonesia. As a reference, the chosen category is "nonhospital childbirth". 
Table 1. Descriptive Statistics of Problems During Pregnancy in Urban Poor Women and Related Factors in Indonesia $(\mathrm{n}=7891)$

\begin{tabular}{|c|c|c|c|c|}
\hline \multirow{2}{*}{ Characteristics } & \multicolumn{2}{|c|}{ Problems during pregnancy } & \multirow{2}{*}{ All } & \multirow{2}{*}{$\mathbf{X}^{2}$} \\
\hline & No & Yes & & \\
\hline Hospital childbirth* & & & & $p<0.001$ \\
\hline - No & $1341(61.68 \%)$ & $3063(53.58 \%)$ & $4404(55.81 \%)$ & \\
\hline - Yes & $833(38.32 \%)$ & $2654(46.42 \%)$ & $3487(44.19 \%)$ & \\
\hline Age $($ mean $) * *$ & $2174(31.36)$ & $5717(31.30)$ & $7891(31.32)$ & $\mathrm{p}<0.001$ \\
\hline Education level* & & & & $\mathrm{p}<0.001$ \\
\hline - No education (ref.) & $18(0.83 \%)$ & $7(0.12 \%)$ & $25(0.32 \%)$ & \\
\hline - Primary & $483(22.22 \%)$ & $600(10.50 \%)$ & $1083(13.72 \%)$ & \\
\hline - Secondary & $1410(64.86 \%)$ & $3436(60.10 \%)$ & $4846(61.41 \%)$ & \\
\hline - Higher & $263(12.10 \%)$ & $1674(29.28 \%)$ & $1937(24.55 \%)$ & \\
\hline Work status* & & & & $p<0.001$ \\
\hline - No work (ref.) & $1208(55.57 \%)$ & $2879(50.36 \%)$ & $4087(51.79 \%)$ & \\
\hline - Work & $966(44.43 \%)$ & $2838(49.64 \%)$ & $3804(48.21 \%)$ & \\
\hline Marital status* & & & & $\mathrm{p}<0.001$ \\
\hline - Never married (ref.) & $0(0.00 \%)$ & $3(0.05 \%)$ & $3(0.04 \%)$ & \\
\hline - Married/Living with Partner & $2079(95.63 \%)$ & $5588(97.74 \%)$ & $7667(97.16 \%)$ & \\
\hline - Divorced/Widowed & $95(4.37 \%)$ & $126(2.20 \%)$ & $221(2.80 \%)$ & \\
\hline Parity (mean)** & $2174(2,47)$ & $5717(2.27)$ & $7891(2.33)$ & $\mathrm{p}<0.001$ \\
\hline Health insurance* & & & & $\mathrm{p}<0.001$ \\
\hline - No (ref.) & $904(41.58 \%)$ & $1714(29.98 \%)$ & $2618(33.18 \%)$ & \\
\hline - Yes & $1270(58.42 \%)$ & $4003(70.02 \%)$ & $5273(66.82 \%)$ & \\
\hline Antenatal care* & & & & $\mathrm{p}<0.001$ \\
\hline$-<4$ times (ref.) & $513(23.60 \%)$ & $994(17.39 \%)$ & $1507(19.10 \%)$ & \\
\hline$-\geq 4$ times & $1661(76.40 \%)$ & $4723(82.61 \%)$ & $6384(80.90 \%)$ & \\
\hline
\end{tabular}

* Chi-Square test was used for dichotomous variables. /**T-test for continuous variables.

Table 2. Binary Logistic Regression of Hospital Childbirth in Urban Poor Communities in Indonesia $(\mathrm{n}=7891)$

\begin{tabular}{lccc}
\hline \multirow{2}{*}{\multicolumn{1}{c}{ Predictor }} & \multicolumn{3}{c}{ Childbirth in Hospital } \\
\cline { 2 - 4 } & OR & Lower Bound & Upper Bound \\
\hline Problems during pregnancy: Yes & 1.056 & 0.948 & 1.177 \\
Age & $1.049^{* * * *}$ & 1.039 & 1.059 \\
Education level: Primary & 0.765 & 0.323 & 1.815 \\
Education level: Secondary & 1.255 & 0.533 & 2.955 \\
Education level: Tertiary & $2.506^{*}$ & 1.059 & 5.929 \\
Work status: work & 1.021 & 0.927 & 1.125 \\
Marital status: Married/Living with Partner & 0.000 & 0.000 & 0.000 \\
Marital status: Divorced/Widowed & 0.000 & 0.000 & 0.000 \\
Parity & $0.816^{* * *}$ & 0.777 & 0.857 \\
Health insurance: Yes & $1.933^{* * *}$ & 1.744 & 2.143 \\
Antenatal care: $\geq 4$ times & 1.059 & 0.934 & 1.201 \\
\hline
\end{tabular}

$* \mathrm{p}<0.05 ; * * \mathrm{p}<0.01 ; * * * \mathrm{p}<0.001$.

Table 2 shows that "problems during pregnancy" were not proven as a determinant of the use of hospital for delivery in poor women in Indonesia. There is no significant difference in the 
category of "problems during pregnancy" in the use of hospital for delivery in urban poor women in Indonesia.

Table 2 informs that age is proven to be one of the determinants of hospital use for poor urban women in Indonesia. While in the education level category, urban poor women with tertiary education are 2.506 times more likely to use hospitals for delivery than urban poor women who are not in school (OR 2.506; 95\% CI 1.059-5.929).

$\mathrm{T}$ Table 2 shows that marital status is not a determinant of the use of hospital for delivery in urban poor women in Indonesia. While parity is significantly proven as one of the determinants that influence the use of hospital for delivery in urban poor women in Indonesia.

Table 2 informs that urban poor women covered by health insurance are 1.933 times more likely to use the hospital for delivery than those without health insurance (OR 1.933; 95\% CI 1.744-2.143). While the frequency of antenatal care by urban poor women is not proven as a determinant of the use of hospitals for delivery in Indonesia.

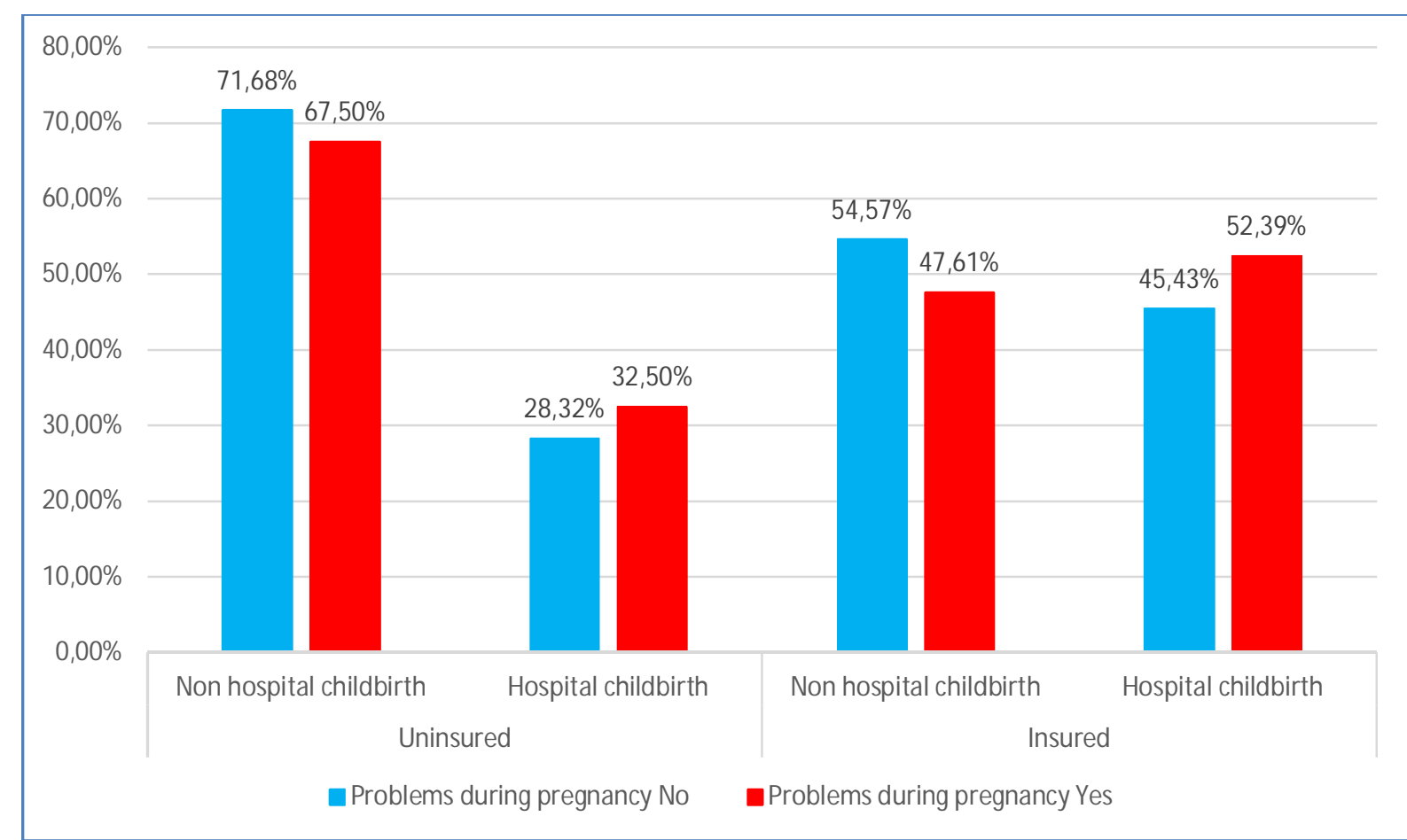

Figure 1. Distribution of Hospital-based childbirth base on health insurance ownership and problems during pregnancy in urban poor women in Indonesia, IDHS 2017

Figure 1 is a description of the distribution of deliveries in hospitals based on health insurance ownership and the experience of problems during pregnancy in urban poor women in Indonesia. Figure 1 shows that urban poor women who experience problems during pregnancy (the red one) and do not have health insurance are more dominant in delivering labor not in hospitals. While urban poor women who experience problems during pregnancy and have health insurance are more dominant in childbirth at the hospital. 


\section{DISCUSSION}

The results found that problems during pregnancy were not predictors of the use of hospitals for delivery in urban poor women in Indonesia. This means that urban poor women, even though they are experiencing problems with their pregnancy, cannot use hospitals for childbirth. The results of this study reaffirm that there are problems in the urban poor in accessing hospitals. Several studies have found that the cost factor is the dominant factor that is a barrier in the urban poor community ${ }^{13,14,15}$.

There are at least two cost factors found in several studies that have become a barrier for people to access health services in various countries. First is the cost to get health services $16,17,18$ ${ }^{19}$, and second, the costs required for transportation ${ }^{20,21,22}$. The combination of the two types of barrier cost can make urban poor women increasingly have no access to deliver to the hospital, even though they feel they have a disruption in their pregnancy.

Another factor found to be a barrier is the low level of education in the urban poor community. The low level of education makes the ability of the urban poor community to communicate and access information about health encounters obstacles and is limited. The relationship between low levels of education as a barrier to access to health care facilities is in line with the results of research in several countries, including in Malaysia ${ }^{23}$, Korea ${ }^{24}$, China, Ghana, India ${ }^{25}$, Australia ${ }^{26}$, USA ${ }^{27,28}$, and several other countries ${ }^{29}$.

Health insurance ownership was found to be a predictor of the use of hospitals for delivery in urban poor women in Indonesia. This condition is consistent with the results of previous studies on health costs as a barrier to access to health services. Insurance ownership is one of the solutions to improve urban poor people's access to health care facilities ${ }^{30,31,32,33}$.

In the Indonesian context, the government has provided subsidies by including membership contribution assistance mechanisms for the poor in the National Health Insurance (JKN). But some of the results of research that conduct evaluations, in general, still show that the health service system that runs in Indonesia is still pro-rich for public access to health services in hospitals ${ }^{34,35}$. While access to services found to be pro-poor is only demonstrated in health services at the primary level, or at the Health Center (Puskesmas) ${ }^{36,37}$.

\section{CONSLUSIONS}

Based on the findings of the study it can be concluded that "problem during pregnancy" is not a predictor of the use of hospital for delivery in urban poor women in Indonesia. The determinants or variables that influence, on the use of hospital for delivery are age, level of education, parity, and ownership of health insurance.

\section{Declaration of conflicting interests}

The author(s) declared no potential conflicts of interest with respect to the research, authorship, and/or publication of this article.

\section{Acknowledgments}

The author would like to thank the ICF International, who has agreed to allow the 2017 IDHS data to be analyzed in this article.

\section{Funding}

Nil 


\section{REFERENCES}

1. Directorate of Family Health-The Indonesia MOH. The 2016 Directorate of Family Health Annual Report. Jakarta; 2016. http://kesga.kemkes.go.id/images/pedoman/Laptah TA 2016 Dit Kesga.pdf.

2. National Population and Family Planning Board, Statistics Indonesia, Ministry of Health, The DHS Program. Indonesia Demographic and Health Survey 2017. Jakarta; 2018. https://www.dhsprogram.com/pubs/pdf/FR342/FR342.pdf.

3. Chadha S, Kumar S, Singh JV, Sehgal S, Baijal V, Raghav SK. Prevalence of ocular morbidities and its socio-demographic correlates in an urban slum of western Uttar Pradesh, India. Indian J Community Heal. 2016;28(2):174-178.

4. George CE, Norman G, Wadugodapitya A, et al. Health issues in a Bangalore slum: Findings from a household survey using a mobile screening toolkit in Devarajeevanahalli(. BMC Public Health. 2019;19(1):Article number 456. doi:10.1186/s12889-019-6756-7

5. Clark S, Madhavan S, Kabiru C. Kin support and child health: Investigating two approaches in an African slum. Soc Sci Res. 2018;76:105-119. doi:10.1016/j.ssresearch.2018.08.001

6. Mei Y, Zhao X, Lin L, Gao L. Capitalization of urban green vegetation in a housing market with poor environmental quality: Evidence from Beijing. J Urban Plan Dev. 2018;144(3). doi:10.1061/(ASCE)UP.1943-5444.0000458

7. Nekoei-Moghadam M, Heidari N, Amiresmaeili M, Heidarijamebozorgi M. Identifying the health problems of slum residents using social determinants of health: Kerman, Iran. Int J Health Plann Manage. 2019;34(2):e1179-e1187. doi:10.1002/hpm.2755

8. Islam M, Sultana N. Risk factors for pregnancy related complications among urban slum and non-slum women in Bangladesh. BMC Pregnancy Childbirth. 2019;19(1):Article number 235. doi:10.1186/s12884-019-2392-6

9. Van Der Heijden J, Gray N, Stringer B, et al. "Working to stay healthy", health-seeking behaviour in Bangladesh's urban slums: A qualitative study. BMC Public Health. 2019;19(1):Article number 600. doi:10.1186/s12889-019-6750-0

10. Yuan Y, Louis C, Cabral H, Schneider JC, Ryan CM, Kazis LE. Socioeconomic and Geographic Disparities in Accessing Nursing Homes With High Star Ratings. J Am Med Dir Assoc. 2018. doi:10.1016/j.jamda.2018.05.017

11. Karuaihe ST, Wandschneider PR. Limited access to services for the urban poor in Windhoek, Namibia. Dev South Afr. 2018;35(4):466-479. doi:10.1080/0376835X.2018.1475219

12. Lam HY, De Vera R, Rivera AS, et al. Describing the health Service Delivery Network of an urban poor area and a rural poor area. Acta Med Philipp. 2018;52(5):438-446.

13. Jacobs C, Michelo C, Moshabela M. Implementation of a community-based intervention in the most rural and remote districts of Zambia: A process evaluation of safe motherhood action groups. Implement Sci. 2018;13(1):Article number 74. doi:10.1186/s13012-0180766-1

14. $\mathrm{Xu} \mathrm{Y,} \mathrm{He} \mathrm{J,} \mathrm{Lin} \mathrm{S,} \mathrm{et} \mathrm{al.} \mathrm{General} \mathrm{analysis} \mathrm{of} \mathrm{factors} \mathrm{influencing} \mathrm{cataract} \mathrm{surgery} \mathrm{practice}$ in Shanghai residents. BMC Ophthalmol. 2018;18(1):Article number 102. doi:10.1186/s12886-018-0767-5

15. Pillai N, Foster N, Hanifa Y, et al. Patient costs incurred by people living with HIV/AIDS prior to ART initiation in primary healthcare facilities in Gauteng, South Africa. PLoS One. 2019;14(2):Article number e0210622. doi:10.1371/journal.pone.0210622 
16. Aguiar PNJ, Roitberg F, Noia Barreto CM, Adashek JJ, Del Giglio A, Lopes, G.L. J. Back to the Future: In the Era of Cost-Effectiveness Analysis, Affordability Is a Limiting Factor for Patients' Access to Innovative Cancer Treatments. Value Heal Reg Issues. 2019;20:4750. doi:10.1016/j.vhri.2018.12.003

17. Wakerman J, Sparrow L, Thomas SL, Humphreys JS, Jones M. Equitable resourcing of primary health care in remote communities in Australia's Northern Territory: A pilot study. BMC Fam Pract. 2017;18(1):Article number 75. doi:10.1186/s12875-017-0646-9

18. Kaminska ME, Wulfgramm M. Universal or commodified healthcare? Linking out-ofpocket payments to income-related inequalities in unmet health needs in Europe. $J$ Eur Soc Policy. 2019;29(3):345-360. doi:10.1177/0958928718774261

19. Zombré D, De Allegri M, Platt RW, Ridde V, Zinszer K. No TitleAn Evaluation of Healthcare Use and Child Morbidity 4 Years After User Fee Removal in Rural Burkina Faso. Matern Child Health J. 2019;23(6):777-786. doi:10.1007/s10995-018-02694-0

20. Kabia E, Mbau R, Oyando R, et al. "We are called the et cetera": Experiences of the poor with health financing reforms that target them in Kenya. Int J Equity Health. 2019;18(1):Article number 98. doi:10.1186/s12939-019-1006-2

21. Sanga ES, Mukumbang FC, Mushi AK, Lerebo W, Zarowsky C. Understanding factors influencing linkage to HIV care in a rural setting, Mbeya, Tanzania: qualitative findings of a mixed methods study. BMC Public Health. 2019;19(1):Article number 383. doi:10.1186/s12889-019-6691-7

22. Varela C, Young S, Mkandawire N, Groen RS, Banza L, Viste A. TRANSPORTATION BARRIERS to ACCESS HEALTH CARE for SURGICAL CONDITIONS in MALAWI a cross sectional nationwide household survey 11 Medical and Health Sciences 1117 Public Health and Health Services. BMC Public Health. 2019;19(1):Article number 264. doi:10.1186/s12889-019-6577-8

23. Chuah FLH, Tan ST, Yeo J, Legido-Quigley H. The health needs and access barriers among refugees and asylum-seekers in Malaysia: A qualitative study. Int J Equity Health. 2018;17(1):Article number 120. doi:10.1186/s12939-018-0833-x

24. Hwang J. Understanding reasons for unmet health care needs in Korea: What are health policy implications? BMC Health Serv Res. 2018;18(1):Article number 557. doi:10.1186/s12913-018-3369-2

25. Kailembo A, Preet R, Stewart Williams J. Socioeconomic inequality in self-reported unmet need for oral health services in adults aged 50 years and over in China, Ghana, and India. Int J Equity Health. 2018;17(1):Article number 99. doi:10.1186/s12939-018-0812-2

26. Durham J, Fa' Avale N, Fa' Avale A, et al. The impact and importance of place on health for young people of Pasifika descent in Queensland, Australia: A qualitative study towards developing meaningful health equity indicators. Int J Equity Health. 2019;18(1):Article number 81. doi:10.1186/s12939-019-0978-2

27. Berdahl TA, Kirby JB. Patient-Provider Communication Disparities by Limited English Proficiency (LEP): Trends from the US Medical Expenditure Panel Survey, 2006-2015. J Gen Intern Med. 2019;34(8):1434-1440. doi:10.1007/s11606-018-4757-3

28. Samari G, McNall M, Lee KS, Perlstadt H, Nawyn S. Socioeconomic Status and the Physical and Mental Health of Arab and Chaldean Americans in Michigan. J Immigr Minor Heal. 2019;21(3):497-507. doi:10.1007/s10903-018-0768-8

29. Roberts T, Miguel Esponda G, Krupchanka D, Shidhaye R, Patel V, Rathod S. Factors associated with health service utilisation for common mental disorders: A systematic 
review. BMC Psychiatry. 2018;18(1):Article number 262. doi:10.1186/s12888-018-18371

30. Tilahun H, Atnafu DD, Asrade G, Minyihun A, Alemu YM. Factors for healthcare utilization and effect of mutual health insurance on healthcare utilization in rural communities of South Achefer Woreda, North West, Ethiopia. Health Econ Rev. 2018;8(1). doi:10.1186/s13561-018-0200-Z

31. Lee Y-H, Ang TFA, Chiang TC, Kaplan WA. Growing concerns and controversies to Taiwan's National Health Insurance-what are the lessons from mainland China, South Korea and Singapore? Int J Health Plann Manage. 2018;33(1):e357-e366. doi:10.1002/hpm.2387

32. Müllerschön J, Koschollek C, Santos-Hövener C, Kuehne A, Müller-Nordhorn J, Bremer $\mathrm{V}$. Impact of health insurance status among migrants from sub-Saharan Africa on access to health care and HIV testing in Germany: A participatory cross-sectional survey 11 Medical and Health Sciences 1117 Public Health and Health Services 11 Medical and Healt. BMC Int Health Hum Rights. 2019;19(1). doi:10.1186/s12914-019-0189-3

33. Nandi S, Schneider H, Garg S. Assessing geographical inequity in availability of hospital services under the state-funded universal health insurance scheme in Chhattisgarh state, India, using a composite vulnerability index. Glob Health Action. 2018;11(1):Article number 1541220. doi:10.1080/16549716.2018.1541220

34. Laksono AD, Wulandari RD, Soedirham O. Regional Disparities of Health Center Utilization in Rural Indonesia. Malaysian J Public Heal Med. 2019;19(1).

35. Laksono AD, Wulandari RD, Soedirham O. Urban and Rural Disparities in Hospital Utilization among Indonesian Adults. Iran J Public Health. 2019;48(2):247-255. http://ijph.tums.ac.ir/index.php/ijph/article/view/16143.

36. Johar M, Soewondo P, Pujisubekti R, Satrio HK, Adji A. Inequality in access to health care, health insurance and the role of supply factors. Soc Sci Med. 2018;213:134-145. doi:10.1016/j.socscimed.2018.07.044

37. Wulandari RD, Laksono AD. Urban-Rural Disparities in The Utilization of Primary Health Care Center Among Elderly in East Java, Indonesia. J Adm Kesehat Indones. 2019;7(2):in press. doi:10.20473/jaki.v7i2.2019.\%25p 